\title{
The Analysis of the Effects of Variables Used in the Formation of PISA Scores on Job Index Values for OECD Member States
}

\author{
Ozlem Deniz Basar ${ }^{1} \&$ Elif Guneren Genc ${ }^{2}$ \\ ${ }^{1}$ Department of Business, Istanbul Commerce University, Istanbul, Turkey \\ ${ }^{2}$ Department of Banking and Finance, Istanbul Commerce University, Istanbul, Turkey \\ Correspondence: Elif Guneren Genc, Ph.D., Department of Banking and Finance, Istanbul Commerce University, \\ Istanbul, Turkey.
}

Received: February 12, 2018

Accepted: March 1, 2018

Online Published: March 20, 2018

doi:10.5430/ijhe.v7n2p58

URL: https://doi.org/10.5430/ijhe.v7n2p58

\begin{abstract}
The quality of an adult's daily working life comprising the major part of his life, will also increase the quality of his social life. Having a good working life is also associated with having a job that one desires and regards it as suitable for himself. But as will be acknowledged all over the world, the quality of a job that one can have will be affected in direct proportion to the quality of his education and his ability to meet company's demands. Starting from this point of view, some of the variables used to obtain PISA scores for the year 2015 were identified for the purpose of the examination of qualified education, and that to which extent they influence the job index variable, included in the OECD Better Life index to represent a decent work, was investigated using ordinal logistic regression analysis.
\end{abstract}

Keywords: ordinal regression analysis, PISA scores, OECD countries, OECD better life index, job index

\section{Introduction}

Today, we spend a major part of our daily life at at workplace, a significant part of our lives working. The quality of working life plays an important role in terms of the life quality of working people. The quality of working life consists of the profit that the work derives, and of the thoughts, attitudes and expectations of the employees about their work, which come to existence throughout the socioeconomic development of the society. Moreover, a balanced workplace where employees are satisfied with regard to the conditions of working life, safety level of work, and have enough resources to meet demands of the work, plays an important role in the welfare, motivation and productivity of employees.

The evaluation of the progress of societies and countries in terms of how well the factors that affect people's lives are improving and progressing rather than only in terms of the increase of countries will be more meaningful approach. For this purpose, the OECD built the "Better Life Index" for the first time in 2011. In The Better Life Index, the welfare of countries are compared in a total of eleven fields, including society, education, environment, civil participation, health, housing, income, work, life satisfaction, safety and work-life balance. Each of these eleven indicators which reflect the social and economic conditions of countries, consists of four variables varying between one to four in itself. Each indicator is calculated by the weighted average of the variables. The better life index is available separately for male and female, in order to determine the intersexual difference of life quality.

Since having a job today, is considered as the most important determinant for people's prosperity, job creation is one of the most important issues of policy makers. But, when the countries' economies solely focus on job creation, the work quality becomes ignored. Work quality not only increases the welfare of individuals but also significantly contributes to economic performance in terms of increasing labor force participation, sustainability and productivity. The influence of work and employment on people's welfare has been investigated from different perspectives and using different approaches (Bustillo Liorente \& Macias, 2005). Therefore, it is not enough only to consider the number of employees, also consider the quantity and quality of the created works, and calculating the contribution they made to the welfare of people are the important issues we confront.

Having a job is important for individuals in respect to i. earning income in order to continue their life, ii. making themselves feel happy and independent and accordingly to be satisfied from life while ensuring them to have spiritual pleasure, iii. being appreciated, approved and organizing lives by providing social status to their families and themselves. Taking all these into consideration, having a job, even a quality job becomes apparent both for the 
individual and for the societies. Since the measurement of work quality has different meanings for individuals living in different countries, it makes difficult to compare intercountry socioeconomic groups.

In the "Life Better Index" prepared by the OECD, there are four variables under the main heading of "Job". These variables are "Job Security", "Personal Earnings", "Long-Term Unemployment Rate" and "Employment Rate".

Job Security: Job security, an important factor of employment quality, is expressed as the expected loss of earnings in case of unemployment. It was found in Green's study in 2011 that while labor security results in positive consequences for individual such as life satisfaction and medical condition; insecurity in the labor market has negative effects on that (Green, 2011). Job insecurity can affect profits of companies, reducing society -oriented winning investments as well as company-specific skills and productivity, by shaping people's political views, increasing social unrest, and through the deterioration consumer confidence and saving behaviors (Cazes, Hijzen, \& Saint-Martin, 2015).

Personal Earnings: Compensations from several resources, including fees that come along with employment, personal incomes, salaries and premiums from liberal profession, dividends from investment and distributions, rental income from real estate investments, profit sharing from businesses, other financial benefits are among the income sources of households.

Long-Term Unemployment Rate: Long-term unemployment is defined by calculating the length of the time during which people are unemployed, in many studies and reports published by the International Labor Organization (ILO) on the labor market and employment. According to these studies, those who are unemployed for one year or longer are defined as "long-term unemployed". The people who are unemployed for one year or longer are implied in the long-term unemployed definition of the program of "Struggle With Long-Term Unemployed" which was carried out by the European Commission in 1984 (Sexton, 1988).

The unemployed are defined as people who are not working at the moment, but ready to work and actively look for job. Unemployment can last only for a few weeks or months, in this case, it doesn't constitute a problem. However, unemployment can sometimes last longer. Long-term unemployment can have a major negative impact and lead to loss of talent and further decrease in employability.

The factors affecting long-term unemployment consist of i. increase in total unemployment rates, ii. growth, technological developments and global competition, iii. role of employers and the obstacles in front of the integration to the labor market (Duruel, 2007).

Employment Rate: This rate has referred to those who are over 15 years old, who say they work in a profitable business for at least one hour a week, as the percentage of working age-population. Employment rates are shaped by the politics of governments, within the economic conjuncture, and indicate to which extent labor resources are used. There is a strong relationship between the level of development of the countries and the employment rate. Developing countries have a lower employment rate than developed countries. Besides, the data related to employment rate, and to the statuses of employed persons in the workplace provide information about employee behaviors, working conditions, and socioeconomic groups (Campbell, 2014).

While quality job provides financial prosperity for employees, their lifelong earning levels increase, which results in an increase in the average income levels of both individuals and countries thus increasing life satisfaction.

Large-scale exams are practices used to assess student achievement both nationally and internationally (Dossey, O'Sullivan, \& Gonzales, 2006). Internationally applied large-scale exams are used to compare student performances and student environments between different countries, and to assist countries to identify their national educational problems and to develop new educational policies, by revealing their educational statuses (Grek, 2009).

The most comprehensive international educational research in the sense of large-scale exam is the Program for International Student Assessment (PISA). The Program for International Student Assessment (PISA) is an international questionnaire, which aims to worldwide evaluate 15 year old students' educational systems on the subjects of science, mathematics, reading, cooperative problem solving and financial literacy by testing their knowledge and skills, and which is repeated every three years.

PISA exams have gained significant importance over time as they are determinant for reviewing education policies around the world (Bulle, 2011). Besides, governments can constitute different educational policies by means of PISA exams (Waldow, 2013).

In 2013, Ozmusul studied the school systems of selected OECD countries in four dimensions, namely equity learning equity, school resource equity, participating in education, and digital equity. The writer created an equity index, and 
found that selected OECD countries were insufficient in terms of learning equity, school resource equity, and digital equity (Ozmusul, 2013).

Stevenson and Wolfers found in their studies in 2008 that the life satisfactions of countries increase and they become happier as per capita GDP increases (Stevenson \& Wolfers, 2008).

In January 2016, The United Nations identified 17 targets under the title of "Sustainable Development Goals", to policy and finance of which it will promote. 17 targets include poverty eradication, economic inequality, peace and justice. The aim is to make a better life sustainable, and act collectively at 17 main topics determined for this.

Two of the 17 sustainable development goals of the United Nations is "quality education", and "a decent work and economic growth". Qualified training is an affordable encompassing education without gender discrimination. Decent work and economic growth include the provision of decent work, with full and productive employment, without gender discrimination.

These two sustainable goals are interwoven. In our study, it was aimed to find how much the decent work is influenced by the increase of qualified education for OECD member countries. For this purpose, the "Job" index, which was included in the OECD better life index, was selected as the variable representing "decent work", some variables used in the calculation of PISA scores were defined as variables representing "quality education". Thus, while long-term unemployment preventive employment policies were determined with these two sustainable development goals; to increase and improve the abilities of those who have been unemployed for a long time can be provided through training strategies.

If countries make investment especially for education and training, they will be more successful in guiding young people on subjects where they are capable of. Besides, more productive and better working environment is provided with a better income. Thus, dynamic, sustainable, innovative and people-centered economies can be created.

\section{Methodology}

One of the most commonly used methods in investigating the relationships between variables, if available, in satisfying assumptions is creation of models through related variables. In such cases, the structure of the dependent variable is more important in preferring the model to be used. Logistic regression analysis is an utilized method in case that the dependent variable has a binary (or dichotomous) structure, and that if the independent variable or variables exhibit a categorical or continuous structure (Ranganathan, Pramesh, \& Aggarwal, 2017). The data may not always be binary. Different logistic regression techniques can also be applied in case of presence of categories that more than two. The multinomial logistic regression is used in case of the presence of categories that more than two; ordinal logistic regression analysis is used in case of the presence of categories that more than two, but of presence of a hierarchical ordering according to the importance level. In this study, ordinal logistic regression analysis, in which the dependent variable was categorized hierarchically, was used.

Ordinal variables can be defined as variables that are ordered in themselves, according to their significance levels. Ordering length of hospitalization as "short", "middle" and "long" (Kleinbaum, Kupper, Nizam, \& Muller, 2008, p. 646), ordering work performances of the people as "insufficient", "satisfactory", and "sufficient" (Hosmer, Lemeshow, \& Sturdivant, 2013, p. 289), or ordering motion pictures as one star, two stars, etc. depending on their ratings (Seah, Tsang, \& Ong, 2012, p. 1074) can be given as examples for ordinal sorting. The ordinal logistic regression analysis should be used instead of multinomial logistic regression analysis in cases where dependent variables are in order according to their importance levels (Das \& Rahman, 2011, p. 2).

There are many different ordinal logistic regression models. Partial proportional odds models (Peterson \& Harrell Jr., 1990, p. 208) and Robust ordinal regression (Angilella, Corrente, Greco, \& Słowiński, 2016) are some of the examples of ordinal logistic regression models used in recent years. However, the most commonly used ordinal lojistic model in practice was titled as the proportional odds model (McCullagh, 1980, p. 110). The model is shown in Equation 1.

$$
\operatorname{Pr}[Y \geq j \mid X]=\frac{1}{1+\exp \left[-\left(\alpha_{j}+X \beta\right)\right]}
$$

In the model, $\mathrm{j}=1,2, \ldots, \mathrm{k}$ refer to the levels of the dependent variable (Frank E. Harrell, 2001, p. 333)

The equality definition of the proportional odds model can be indicated in the odds form of inequalities as follows.

$$
\operatorname{Odds}(X)=\frac{P(Y \geq j \mid X)}{1-P(Y \geq j \mid X)}=\frac{P(Y \geq j \mid X)}{P(Y<j \mid X)}
$$


If the equality of the statement of $\mathrm{P}(\mathrm{Y} \geq \mathrm{j} \mid \mathrm{X})$ in the formula (1) is written in the Equation 2, the equality will be as follows (Kleinbaum, Kupper, Nizam, \& Muller, 2008, p. 648).

$$
\operatorname{Odds}(X)=\frac{P(Y \geq j \mid X)}{P(Y<j \mid X)}=\exp \left[\alpha_{j}+X \beta\right]
$$

There are some assumptions to be satisfied in order to apply the ordinal logistic regression. It is parallel lines assumption at which the effect of the independent variable is the same for all categories of the dependent variable (Arfan \& Sherwani, 2017, p.212). In other words, parallel lines assumption means that the correlation between dependent and independent variable does not change for the categories of dependent variable, and thus, to test the unchangeablity of the parameter estimates at cut-off points (Ar1 \& Yildiz, 2014, p.10). The situation that can be encountered among categories in case of the distortion of assumption is shown by Fullerton and $\mathrm{Xu}(2012)$ in Figure 1.
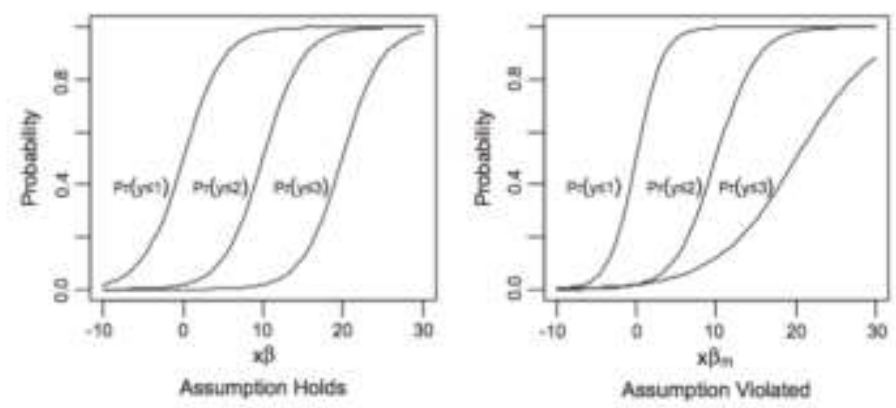

Figure 1. The Parallel Line Assumption (Fullerton \& Xu, 2012, p. 183)

The proportional odds assumption can be verified as follows:

$$
\frac{\gamma_{j}(x=0) /\left(1-\gamma_{j}(x=0)\right)}{\gamma_{j}(x=1) /\left(1-\gamma_{j}(x=1)\right)}=\exp (\beta)
$$

In this equation, $\gamma_{j}(x)=\operatorname{Pr}(Y \leq j \mid x)$ (Jeong, 2006, p. 1260). The assumptions that should be satisfied in order to apply the ordinal logistic regression with this hypothesis are:

- The dependent variable must be measured at the ordinal level.

- One or more of the independent variables must be continuous, categorical, or ordinal

- Multicollinearity should not be exist (two or more variables should not be highly correlated with each other).

- $\quad$ Proportional odds hypothesis should be provided (Reddy \& Alemayehu, 2015, p.152).

\section{Implementation}

The PISA test, which has been applied as a questionnaire to 15 year old students in 72 countries, in order to assess the education systems of the countries, investigates these systems from many aspects, and thus, reveals the differences between the education systems of the countries. In this study, the PISA scores of 34 OECD countries for 2015 were investigated. The data used in the study were compiled from Volume I (OECD, 2016), Volume II (OECD, 2016) and Volume III (OECD, 2017) bulletins, which included OECD PISA scores.

Science, Mathematics, and Reading scores, included in the PISA scores, are major indicators used in comparing countries with each other. In Figure 2, the relevant scores of OECD member countries were compared. 


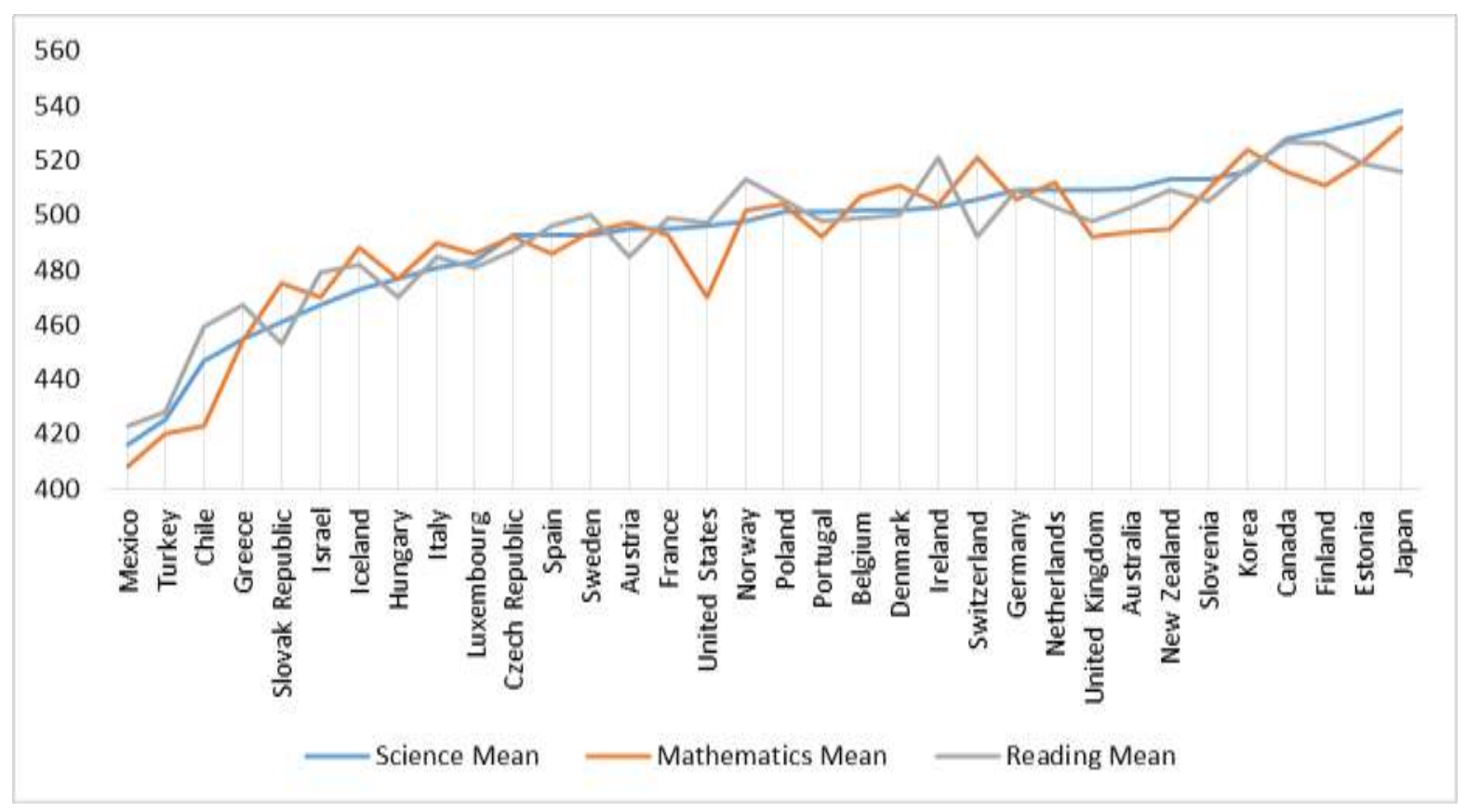

Figure 2. Comparison of Science, Mathematics and Reading Scores of OECD Member Countries

As can be seen from Figure 2, the highest Science and Mathematics score belongs to Japan, while the highest Reading score belongs to Canada. When all scores are examined, it can be determined that the lowest scores belong to Mexico.

Ignoring social conditions of the country, and considering that good education will provide good job opportunities; job index values in the "Better life index" calculated by OECD for 2015 (OECD, 2017) were investigated. The job index values, which have been created with the subtitles of job security which refers to the the risk of becoming unemployed of employed people; personal earnings which refers to the average annual earnings of full-time employees; long-term unemployment rate which refers to the percentage of unemployed people aged 15-64 years old who are actively seeking for a job for the last one year; and employment rate which refers to the ratio of people aged 15-64 years old, working in a job for a fee, is both an indicator of the development of countries, as well as a variable indicating individual's peace in working life. Therefore, job index values were examined for OECD countries.
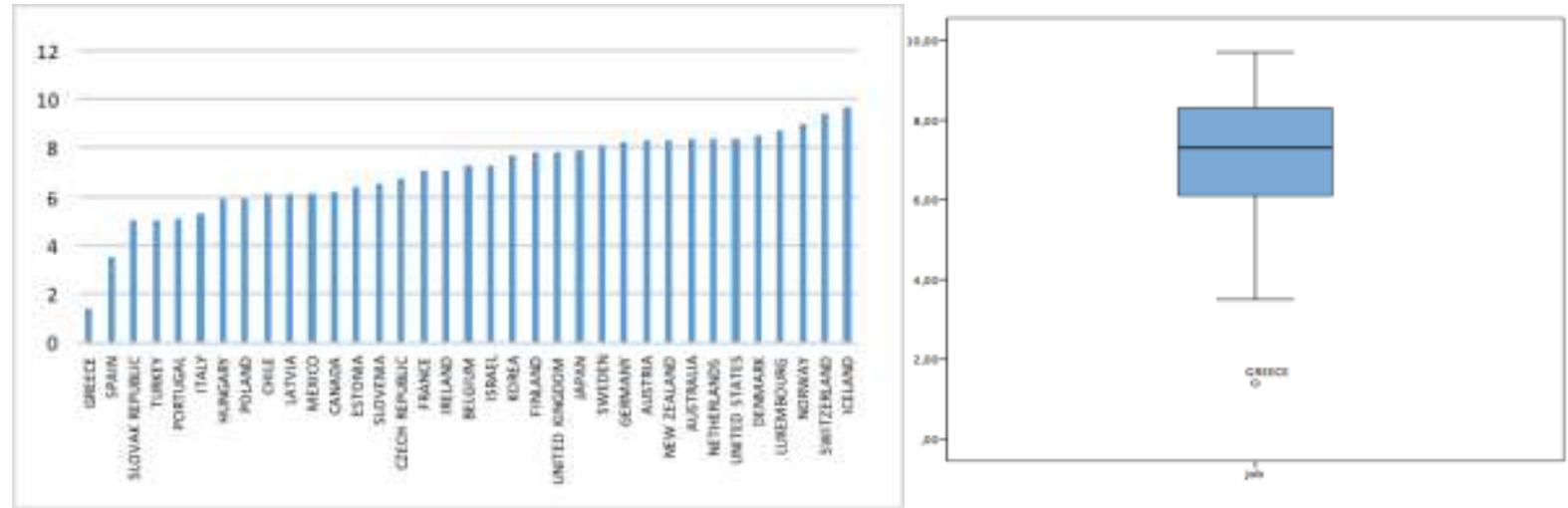

Figure 3. Comparing Jobs Indexes of OECD Member Countries and displaying them with Box Plot

When the Jobs index is examined, the countries with highest job index value, such as Iceland, Switzerland and Norway, draw attention. However, it was observed that the value calculated for Greece is lower than the values calculated for all other countries.

At this stage of the study, the countries' job index values were divided into categories, defined from 1 to 5 , in such a way that 1 implies the range of 0.00 to $1,99,2$ implies the range of 2,00 to 3,99, and the explanation of the job index values of the countries through the values measured by the PISA test were investigated. 
For this purpose, ordinal logistic regression analysis was decided to be used. Jobs index category values were determined as dependent variable, the variables shown in Table 1, regarding some of the questions from the PISA test were determined as independent variables.

Table 1. List of Independent Variables

\begin{tabular}{|c|c|}
\hline Independent Variables' Labels & Names \\
\hline Percentage of 35-44 year-olds with tertiary education. & v1 \\
\hline $\begin{array}{l}\text { A good way to know if something is true is to do an experiment (agree or strongly } \\
\text { agree \%). }\end{array}$ & v2 \\
\hline I generally have fun when I am learning science topics. & v3 \\
\hline I am interested in learning about science. & $\mathrm{v} 4$ \\
\hline Many thingsI learn in my school science subjects will help me to get a job. & v5 \\
\hline $\begin{array}{l}\text { What I learn in my school subjects is important for me because I need this for what } \\
\text { I want to do later on. }\end{array}$ & v6 \\
\hline Watch TV programmes about science (very often or regularly). & v7 \\
\hline Borrow or buy books on science topics. & v8 \\
\hline We have enough laboratory material that all cources can regularly use it. & v9 \\
\hline Our school spends extra money on up-to-date science equipment. & v10 \\
\hline $\begin{array}{l}\text { Percentage of students in schools offering the following science-releated activities } \\
\text { (science club). }\end{array}$ & v11 \\
\hline I want to be one of the best students in my class. & v12 \\
\hline $\begin{array}{l}\text { Percentage of students who agreed/strongly agreed with the following statement: } \\
\text { My parents are interested in my school activities. }\end{array}$ & v13 \\
\hline Percentage of students who expected to complete a university degree. & v14 \\
\hline
\end{tabular}

One of the necessary conditions for the ordinal logistic regression to be applied is to be low of the correlation between independent variables. The correlation between the independent variables is shown in Figure 4.

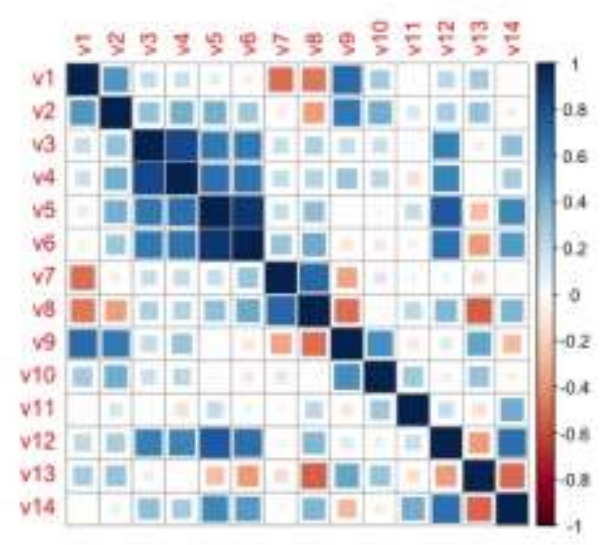

Figure 4. Correlation Values Between Independent Variables

As can be seen in Figure 4, it can be said that there is no high correlation between variables. Starting from this point of view, it has been decided to apply the ordinal regression analysis through relevant variables.

The values which are the incators of goodness of fit for the model to be created by the variables indicated in Table 1 are shown in Table 2. 
Table 2. Model Fitting Information

\begin{tabular}{lllll}
\hline Model & -2 Log Likelihood & Chi-Square & df & Sig. \\
\hline Intercept Only & 84,76 & & & \\
Final & 28,512 & 56,248 & 14 & 0.000 \\
\hline
\end{tabular}

In this test, which is used to test whether the model is suitable for being used in estimations, the model without explanatory variables is compared with the model with explanatory variables. Since p-value yielded lower than 0,05 for the calculated chi-square statistic, it is convinced that the model is suitable for using in estimations.

The goodness-of-fit test, which tests whether the observed data are suitable for fitted model is given in Table 3.

Table 3. Goodness-of-Fit

\begin{tabular}{llll}
\hline & Chi-Square & df & Sig. \\
\hline Pearson & 37,92 & 118 & 0.998 \\
Deviance & 28,512 & 118 & 0.997 \\
\hline
\end{tabular}

According to the result of Pearson chi-square test used for the null hypothesis test, which indicates that the data completely fit model, it can be said that he null hypothesis was accepted, the data fitted model, and so the model created is a good model.

In the logistic regression, R-squared values calculated for the ordinary least squares (OLS) regression models can not be calculated. Instead, the values obtained by different calculation methods and so-called pseudo R-squared are calculated. These values, as stated in the OLS regression, do not give information on to what extent the independent variables explain the percentage of the dependent variable. But, in studies, these calculated values are preferred to be as big as possible.

Table 4. Pseudo R-Square

\begin{tabular}{lll}
\hline $\begin{array}{l}\text { Pseudo } \\
\text { Value }\end{array}$ & R-Square \\
\hline Cox and Snell & 0,809 & \\
Nagelkerke & 0,882 & \\
McFadden & 0,664 &
\end{tabular}

As can be seen from Table 4, the Cox and Snell R-squared value was calculated as 0,809 for model, Nagelkerke $\mathrm{R}$-squared value as 0.882 , and McFadden R-squared value as 0.664 , respectively.

At this stage of the study, ordinal logistic regression model was created for the categories, the dependent variable of which was identified for jobs index, an the resuls are given in Table 5. 
Table 5. Parameter Estimates

\begin{tabular}{|c|c|c|c|c|c|c|c|c|}
\hline & & Estimate & $\begin{array}{l}\text { Std. } \\
\text { Error }\end{array}$ & Wald & Sig. & $e^{\beta}$ & $\begin{array}{l}95 \% \\
\text { Interval } \\
\text { Lower } \\
\text { Bound }\end{array}$ & $\begin{array}{l}\text { Upper } \\
\text { Bound }\end{array}$ \\
\hline \multirow{4}{*}{ Threshold } & {$[\mathrm{job}=1,00]$} & $-114,981$ & 49,469 & 5,402 & 0,02 & \multirow{11}{*}{1,6405} & $-211,939$ & $-18,023$ \\
\hline & {$[\mathrm{job}=2,00]$} & $-113,65$ & 49,348 & 5,304 & 0,021 & & $-210,371$ & $-16,929$ \\
\hline & {$[\mathrm{job}=3,00]$} & $-107,423$ & 46,923 & 5,241 & 0,022 & & $-199,391$ & $-15,455$ \\
\hline & {$[\mathrm{job}=4,00]$} & $-99,433$ & 44,817 & 4,922 & 0,027 & & $-187,272$ & $-11,593$ \\
\hline \multirow{14}{*}{ Location } & v1 & $-0,072$ & 0,076 & 0,893 & 0,345 & & $-0,22$ & 0,077 \\
\hline & v2 & $-0,265$ & 0,256 & 1,075 & 0,3 & & $-0,766$ & 0,236 \\
\hline & v3 & 0,495 & 0,231 & 4,595 & 0,032 & & 0,042 & 0,947 \\
\hline & $\mathrm{v} 4$ & $-0,236$ & 0,173 & 1,857 & 0,173 & & $-0,576$ & 0,104 \\
\hline & v5 & $-0,386$ & 0,273 & 2,009 & 0,156 & & $-0,92$ & 0,148 \\
\hline & v6 & $-0,313$ & 0,206 & 2,307 & 0,129 & & $-0,718$ & 0,091 \\
\hline & v7 & 0,361 & 0,199 & 3,291 & 0,07 & & $-0,029$ & 0,75 \\
\hline & v8 & $-1,108$ & 0,55 & 4,056 & 0,044 & 0,3302 & $-2,187$ & $-0,03$ \\
\hline & v9 & 0,258 & 0,122 & 4,464 & $\mathbf{0 , 0 3 5}$ & 1,2943 & 0,019 & 0,498 \\
\hline & v10 & $-0,191$ & 0,086 & 4,941 & 0,026 & 0,8261 & $-0,359$ & $-0,023$ \\
\hline & v11 & 0,023 & 0,037 & 0,376 & 0,54 & & $-0,05$ & 0,095 \\
\hline & v12 & 0,412 & 0,203 & 4,107 & 0,043 & 1,5098 & 0,014 & 0,81 \\
\hline & v13 & $-0,739$ & 0,374 & 3,915 & 0,048 & 0,4776 & $-1,472$ & $-0,007$ \\
\hline & v14 & $-0,205$ & 0,098 & 4,322 & $\mathbf{0 , 0 3 8}$ & 0,8146 & $-0,398$ & $-0,012$ \\
\hline
\end{tabular}

The threshold values of the coefficients according to job index categories, and the significancy of the coefficients in respect to the variables used are shown in Table 5. When independent variables were examined, following variables were found statistically significant: I generally have fun when I am learning science topics, Borrow or buy books on science topics, We have enough laboratory material that all cources can regularly use it, Our school spends extra money on up-to-date science equipment, I want to be one of the best students in my class, Percentage of students who agreed/strongly agreed with the following statement: My parents are interested in my school activities, Percentage of students who expected to complete a university degree.

It will be possible to talk about the effect of the related coefficient on the dependent variable by expressing the coefficients found significant within the scope of proportional odds ratio principle as the power of number e. The power forms of e's significant coefficients are shown in Table 5. Regarding the interpretation of continuous variables, to what extend increase or decrease occurs with $(\exp \beta-1)^{*} 100$ transformation can be interpreted. Starting from this point of view, it can be said that a change in "I generally have fun when I am learning science topics" variable caused an increase of $64,05 \%$ in job index variable, a change in "We have enough laboratory material that all cources can regularly use it" variable caused a change of $29,43 \%$ in dependent variable, and a change in "I want to be one job index variable of the best students in my class" variable caused an increase of 50,98 \% in job index variable. However, "Borrow or buy books on science topics" variable caused a decrease of $66,98 \%$ in job index variable, "Our school spends extra money on up-to-date science equipment" variable a decrease of $17,39 \%$, "My parents are interested in my school activities" variable a decrease of $52,24 \%$, and "Percentage of students who expected to complete a university degree" variable a decrease of $18,54 \%$.

It was forementioned that the most important assumption for the application of the ordinal logistic regression analysis is the assumption of parallel lines. The hypotheses to be used in testing this assumption will be as follows:

$\mathrm{H}_{0}$ : The parameter estimations pass through the same intersection point.

$\mathrm{H}_{1}$ : The parameter estimations pass through a different intersection point.

(Yavuz, Deveci, Karabulut \& Şentürk, 2014, p. 107). The results for the chi-squared test performed for testing these hypotheses are shown in Table 6. 
Table 6. Test of Parallel Lines

\begin{tabular}{lllll}
\hline Model & -2 Log Likelihood & Chi-Square & df & Sig. \\
\hline Null Hypothesis & 28,512 & & & \\
General & 0 & 28,512 & 42 & 0,944
\end{tabular}

p-value was found greater than 0.05 as a result of the analysis made, which means that hypothesis $\mathrm{H}_{0}$ can not be rejected. Accordingly, it can be said that the categories of job index variable are parallel to each other. Thus, it can be suggested that parallel lines assumption required for the results of regression analysis to be used was satisfied.

\section{Conclusions}

The quality of an adult's daily working life comprising the major part of his life, will also increase the quality of his social life. Having a good working life is also associated with having a job that one desires and regards it as suitable for himself. But as will be acknowledged all over the world, the quality of a job that one can have will be affected in direct proportion to the quality of his education and his ability to meet company's demands. Through PISA tests that have been in use since 2000, it is possible to test how students use knowledge and skills that they achieved in school, in real life. The testability of that gives the opportunity to increase the quality of education.

Improving education and people's enhancing the quality of their own education are also closely related to their future profession and their professional success. Starting from this point of view, that how the variables in the PISA test which was implemented by the OECD in 2015, used to test the qualified education, affect decent work, was investigated by ordinal regression analysis in this study.

In this study for OECD member countries, students' having fun while learning topics in their schools, students' being in possession of enough laboratory materials to use in all courses, and their desire to be one of the best students in their class creates an job index value enhancing effect. However, borrowing or buying a book on science, schools' spend more money for science equipments, families's interests in school activities, and students' expectation to complete college decrease the people's job index values.

Starting from findings, it can be said that transformation of education into entertaining and practical state with materials, decisiveness of student are important factors for students to find a decent job in the future. But, it can be stated that disinclining students with excess equipment, involvement of families in students' tasks, families' expactations of students on receiving an university grade will adversely influence people in finding a decent job.

\section{References}

Angilella , S., Corrente, S., Greco, S., \& Słowiński, R. (2016). Robust Ordinal Regression and Stochastic Multiobjective Acceptability Analysis in multiple criteria hierarchy process for the Choquet integral preference model. Omega(63), 154-169. https://doi.org/10.1016/j.omega.2015.10.010

Arı, E., \& Yıldız, Z. (2014). Parallel Lines Assumption in Ordinal Logistic Regression And Analysis Approaches. International Interdisciplinary Journal of Scientific Research, 1(3), 8-23.

Arfan, M., \& Sherwani, R. (2017, January 1). Ordinal Logit and Multilevel Ordinal Logit Models: An Application on Wealth Index MICS-Survey Data. Pakistan Journal of Statistics \& Operation Research, 13(1), 211-226. https://doi.org/10.18187/pjsor.v13i1.1801

Bulle, N. (2011). Comparing OECD Educational Models through the Prism of PISA. Comparative Education, 503-521. https://doi.org/10.1080/03050068.2011.555117

Bustillo Liorente, R., \& Macias, E. (2005). Job Satisfaction as an Indicator of the Quality of Work. Journal of Behavioral and Experimental Economics, 34(5), 656-673. https://doi.org/10.1016/j.socec.2005.07.027

Campbell, D. (2014). Perspectives on Labour Economics for Development. International Labour Organization, The Labour Market in Developing Countires. Geneva: International Labour Office.

Cazes, S., Hijzen, A., \& Saint-Martin, A. (2015). Measuring and Assessing Job Quality. OECD Social, Employment and Migration Working Papers(174), 1-51. https://doi.org/10.1787/5jrp02kjw1mr-en

Das, S., \& Rahman, R. (2011). Application of Ordinal Logistic Regression Analysis in Determining Risk Factors of Child Malnutrition in Bangladesh. Nutrition Journal, 10(124), 1-11. https://doi.org/10.1186/1475-2891-10-124

Dossey, J., O'Sullivan, C., \& Gonzales, P. (2006). Problem Solving in the PISA and TIMSS 2003 Assessments. Washington: Institue of Education Sciences. 
Duruel, M. (2007). Avrupa Birliğin'de Uzun Dönemli İşsizliğe Karşı Uygulanan İstihdam Politikaları. İ.Ü.İktisat Fakültesi Sosyal Siyaset Konferanslarl 53. Kitap(Özel Say1), 387-390.

Frank E. Harrell, J. (2001). Regression Modeling Strategies, with Applications to Linear Models, Logistic Regression, and Survival Analysis. New York, USA: Springer.

Fullerton, A., \& Xu, J. (2012). The proportional odds with partial proportionality constraints model for ordinal response variables. Social Science Research(41), 182-198. https://doi.org/10.1016/j.ssresearch.2011.09.003

Green, F. (2011). Unpacking the Misery Multiplier: How Employability Modifies the Impacts of Unemployment and Job Insecurity on Life Satisfaction and Mental Health. Journal of Health Economics, 30(2), 265-276. https://doi.org/10.1016/j.jhealeco.2010.12.005

Grek, S. (2009). Governing by Numbers: The PISA "Effect" in Europe. Journal of Education Policy, 23-37. https://doi.org/10.1080/02680930802412669

Hosmer, D. W., Lemeshow, S., \& Sturdivant, R. X. (2013). Applied Logistic Regression (Cilt 3rd Edition). New Jersey, USA: John Wiley \& Sons. https://doi.org/10.1002/9781118548387

Jeong, J.-H. (2006). A Note On Asymptotic Efficiency Of A Regression Coefficient Parameter Under Ordinal Logistic Regression Model. Communications in Statistics - Theory and Methods, 30(7), 1257-1269. https://doi.org/10.1081/STA-100104744

Kleinbaum, D. G., Kupper, L., Nizam, A., \& Muller, K. (2008). Applied Regression Analysis and Other Multivariable Methods. Duxbury, USA: Thomson Brooks/Cole.

McCullagh, P. (1980). Regression Models For Ordinal Data. Journal of the Royal Statistical Society: Series B (Methodological), 42(2), 109-142.

OECD. (2016). PISA 2015 Results (Volume I): Excellence and Equity in Education. Paris: OECD Publishing. https://doi.org/10.1787/9789264266490-21-en

OECD. (2016). PISA 2015 Results (Volume II): Policies and Practices for Successful Schools, PISA. Paris: OECD Publishing. http://dx.doi.org/10.1787/9789264267510-en

OECD. (2017, 10 10). OECD Better Life Index, Job. Retrieved 10 10, 2017, OECD Better Life Index: http://www.oecdbetterlifeindex.org/topics/jobs/ adresinden alındı

OECD. (2017). PISA 2015 Results (Volume III): Students' Well-Being, PISA. Paris: OECD Publishing. http://dx.doi.org/10.1787/9789264273856-en

Ozmusul, M. (2013). Equity Index in the School Systems of Selected Countries. Educational Research and Reviews, $8(18), 1722-1741$.

Peterson, B., \& Harrell Jr., F. (1990). Partial Proportional Odds Models for Ordinal Response Variables . Journal of the Royal Statistical Society: Series C (Applied Statistics), 39(2), 205-217. https://doi.org/10.2307/2347760

Ranganathan, P., Pramesh, C., \& Aggarwal, R. (2017, July). Common pitfalls in statistical analysis: Logistic regression. Perspectives in Clinical Research, 8(3), 148-151.

Reddy, O., \& Alemayehu, E. (2015). Ordinal logistic regression analysis to assess the factors that affect health status of students in Ambo University: a case of natural and computational sciences college, Ambo University. International Journal of Modern Chemistry and Applied Science, 2(3), 153-163.

Seah, C.-W., Tsang, I., \& Ong, Y.-S. (2012, July). Transductive Ordinal Regression. IEEE Transactions On Neural Networks and Learning Systems, 23(7), 1074-1086. https://doi.org/10.1109/TNNLS.2012.2198240

Sexton, J. J. (1988). Long-Term Unemployment: It's wider Labour Market Effects in the Countries of the European Community: A study. Dublin: Office for Official Publications of the European Communities.

Stevenson, B., \& Wolfers, J. (2008). Economic Growth and Subjective Well-Being: Reassessing the Easterlin Paradox. NBER Working Paper(14282), 1-28. https://doi.org/10.3386/w14282

Waldow, F. (2013). PISA under Examination: Changing Knowledge, Changing Tests, and Changing Schools. Comparative Education, 536-537. https://doi.org/10.1080/03050068.2013.826046

Yavuz, S., Deveci, M., Karabulut, T., \& Şentürk, E. (2014). Sıralı Lojistik Regresyon Analiziyle Üniversite Öğrencilerinin Kent Memnuniyetini Etkileyen Faktörlerin Belirlenmesi: Erzincan Üniversitesi Örneği. Cumhuriyet Universitesi Journal of Economics and Administrative Sciences, 15(1), 95-114. 